\section{Is sea level rising or falling?}

SIR - Sahagian et al. ${ }^{1}$ estimated that the net effect of groundwater mining, wetland drainage, deforestation and water impoundment in reservoirs adds $0.54 \mathrm{~mm}$ per year to global sea-level rise (SLR). Our calculations, however, suggest that these processes may have acted to reduce sea-level rise by an amount comparable to that observed. Further, it is improbable that water diversions within internally draining basins (for example the Caspian

\begin{tabular}{lc}
\multicolumn{2}{c}{$\begin{array}{c}\text { ANTHROPOGENIC CONTRIBUTIONSTO } \\
\text { SEA-LEVEL RISE OVER THE PAST 6OYEARS }\end{array}$} \\
\hline \multicolumn{1}{c}{ Process } & Sea-level rise $\left(\mathrm{mm} \mathrm{yr}^{-1}\right)$ \\
Groundwater mining* & 0.39 \\
$\begin{array}{l}\text { Deforestation } \\
\text { combustion, oxidation; }\end{array}$ & 0.030 \\
$\quad \begin{array}{l}\text { runoff } \\
\text { Wetlands loss* }\end{array}$ & -0.15 \\
Reservoirs and dams & 0.006 \\
$\quad$ storage & -0.23 \\
infiltration & -0.69 \\
evaporation & -0.047 \\
Irrigation & -0.37 \\
infiltration & -0.57 \\
evapotranspiration & $\mathbf{1 . 6 3}$ \\
Total & \\
\hline
\end{tabular}

*From ref. 1.

and Aral seas) will directly affect SLR.

The direct anthropogenic contribution to sea-level rise over a specified time period $\left(\mathrm{SLR}_{a}\right)$ is: $\mathrm{SLR}_{a}=(G+D+W)-$ $(R+I)$, where $G$ is SLR due to groundwater mining; $D$ is SLR due to deforestation; $W$ is SLR due to drainage of wetlands; $R$ is SLR reduction due to impoundment in reservoirs; and $I$ is SLR reduction due to irrigation. Strictly speaking, the terms are not entirely independent; for example, part of mined groundwater goes into irrigation. Here we estimate values for $D$, $R$ and $I$, as discussed below.

The net atmospheric carbon release from tropical deforestation $(D)$ ranges from 1.1 to $3.6 \times 10^{15} \mathrm{~g} \mathrm{C} \mathrm{yr}^{-1}$ (ref. 2), with a likely mean of $1.7 \times 10^{15} \mathrm{~g} \mathrm{C} \mathrm{yr}^{-1}$ (R. A. Houghton, personal communication). Complete combustion of vegetative cellulose produces $\mathrm{CO}_{2}$ and $\mathrm{H}_{2} \mathrm{O}: 6 \mathrm{O}_{2}$ $+\mathrm{C}_{6} \mathrm{H}_{10} \mathrm{O}_{5} \rightarrow 6 \mathrm{CO}_{2}+5 \mathrm{H}_{2} \mathrm{O}$. The mass of carbon burned each year is equivalent to $2.125 \mathrm{~km}^{3} \mathrm{H}_{2} \mathrm{O}$, or only $0.006 \mathrm{~mm} \mathrm{yr}^{-1}$ SLR, even if all of the water flowed to the

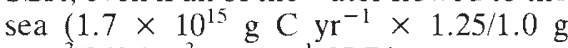
$\mathrm{cm}^{-3} / 360 \mathrm{~km}^{3} 1 \mathrm{~mm}^{-1}$ SLR).

The water content of vegetation cleared each year is obtained using a dry-to-wet biomass ratio of 0.25 (ref. 1). Conversion of the carbon to water yields $8.5 \times 10^{15} \mathrm{~g}$ $\mathrm{H}_{2} \mathrm{O}$, equivalent to a $0.024 \mathrm{~mm} \mathrm{yr}^{-1} \mathrm{SLR}$, if all that water were added to the ocean $\left(1.7 \times 10^{15} \mathrm{~g} \mathrm{C} \times 4 \times 1.25 / 1.0 \mathrm{~g} \mathrm{~cm}^{-3} / 1\right.$ $\mathrm{mm} \mathrm{yr}^{-1}$ SLR).

These figures ${ }^{2}$ include burning, topsoil oxidation, shifting cultivation and longterm decay of wood, but not possible changes in runoff resulting from deforestation. Forest clearing may increase runoff in some cases and decrease it in others. One recent estimate ${ }^{3}$ suggests a net decrease in runoff from deforestation of $356 \mathrm{~mm} \mathrm{yr}^{-1}$. Given an annual deforestation rate of $15.4 \times 10^{10} \mathrm{~m}^{2} \mathrm{yr}^{-1}$ (ref. 4), the reduction of runoff may be approximately $55 \mathrm{~km}^{3} \mathrm{yr}^{-1}$, equivalent to -0.15 $\mathrm{mm} \mathrm{yr}^{-1}$ SLR.

A major reduction in SLR comes from sequestration of river flow behind dams $(R)$. Sahagian et al. ${ }^{1}$ significantly underestimate the volume of water impounded by dams ${ }^{5.6}$. The largest reservoirs ( $>3$ million $\mathrm{m}^{3}$; ref. 7) have a total storage capacity of 3,991 $\mathrm{km}^{3}$. A more plausible value is approximately $5,000 \mathrm{~km}^{3}$ (ref. 8), equivalent to $14 \mathrm{~mm} \mathrm{SLR}$, at an average annual rate of

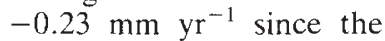
$1930 \mathrm{~s}$.

This storage capacity represents a lower bound of SLR reduction from reservoirs. Additional reductions come from seepage and surface evaporation. Percolation beneath reservoirs recharges aquifers, ultimately increasing groundwater discharge to the sea, but this effect could be relatively small over short (100-yr) periods. If annual seepage losses due to deep percolation from reservoirs is about $5 \%$ of reservoir volume ${ }^{9}$, this amounts to 250 $\mathrm{km}^{3}$, averaging $0.69 \mathrm{~mm} \mathrm{yr}^{-1}$ withheld from SLR over the past 60 years.

Shiklomanov ${ }^{8}$ estimates an annual loss of $170 \mathrm{~km}^{3}$ by evaporation from reservoirs in 1990 . A portion of the evaporated water is stored as vapour in the atmosphere, while the remainder returns to the surface cyclically as precipitation, a part of which flows to the sea. Although the fraction of evaporation withheld is uncertain, assuming it is only 10 per cent would reduce SLR by $0.047 \mathrm{~mm} \mathrm{yr}^{-1}(170 / 360 \times 0.1)$.

Similarly, losses of irrigation water $(I)$ to deep seepage and evaporation lessen the anthropogenic input to SLR. In 1989, 232.8 million hectares were under irrigation ${ }^{10}$. Multiplying by the average annual per hectare water use of $11,400 \mathrm{~m}^{3}$ (ref. 11) gives a volume of $2,654 \mathrm{~km}^{3}$, very close to Shiklomanov's estimate ${ }^{\gamma}$ of 2,680 $\mathrm{km}^{3} \mathrm{H}_{2} \mathrm{O}$ withdrawn in 1990 .

Irrigation efficiency is a measure of the fraction of applied water that is used consumptively, namely that is taken up and evapotranspired by crops. If the consumptive loss of water in irrigation is 2,050 $\mathrm{km}^{3} \mathrm{yr}^{-1}$ (ref. 8), and if - as in the case of evaporation from reservoirs - $10 \%$ remains in the atmosphere as added vapour, then the amount withheld through evapotranspiration is $0.57 \mathrm{~mm} \mathrm{yr}^{-1}$.

The evaporation of $76 \%$ of irrigation water leaves a remaining $24 \%$ lost in seepage, only a small part of which replenishes aquifers. If, as in the case of reservoirs, only $5 \%$ of the water applied in irrigation ends up in deep percolation, the amount withheld is $0.37 \mathrm{~mm} \mathrm{yr}^{-1}$. These estimates are summarized in the table.

\section{Gornitz}

\section{Rosenzweig}

Goddard Space Flight Center, Institute for Space Studies,

Columbia University of New York, 2880 Broadway,

New York, New York 10025, USA

D. Hillel

Department of Plant, Soil

and Environmental Sciences,

University of Massachusetts,

Amherst, Massachusetts 01003,

USA

1. Sahagian, D. L. et al. Nature 367, 54-57 (1994).

2. Houghton, R. A. Clim Change 19, 99-118 (1991)

3. Henderson-Sellers, A. et al. J. geophys. Res. 98. 7289 7315 (1993).

Aldous, P. Science 259, 1390 (1993)

5. Chao, B. F. Nature 370, 258 (1994).

6. Rodenburg, E. Nature 370, 258 (1994

. Mermel. T. W in Water Power and Dam Construction Handbook 1992 (Reed. Sutton. 1992).

8. Shiklomanov. I. A. in Water in Crisis - a Guide to the World's Freshwater Resources (ed. Gieick, P. H.) 13--24 (Oxford Univ. Press, New York, 1993).

9. Gleick, P. H. Energy 17, 735-747 (1992)

10. Gleick, P. H. in Water in Crisis - a Guide to the World's Freshwater Resources (ed. Gleick, P. H.) 266-267 (Oxford Univ. Press, New York. 1993).

11. Postel, S. Water for Agriculture: Facing the Limits (Worldwatch institute. Washington DC. 1989)

\section{Eco-friendly cups?}

SIR - Hocking ${ }^{1}$ has not compared like with like, as far as I can see. He compared the costs of production of reusable and disposable cups, but although he then added to the reusables the cost of reuse, he did not add to the disposables the cost of disposal.

If without disposal costs a ceramic or glass cup must be used about 40 times before the drinker uses less energy than drinking out of styrofoam or paper (and that's not counting those who reuse reusable cups several times without intervening washing), how many less times do we have to drink from reusables to make them equivalent to disposables once disposal costs are counted? Already, 40 drinks is perhaps only about one month's use, far less time than most of us manage to keep a cup.

\section{Alexander H. Harcoun}

Department of Anthropology,

University of California,

Davis,

California 95616-8522,

USA 